\title{
Mature Cystic Teratoma of the Fallopian Tube: Case Report
}

Fallop Tüpünün Matür Kistik Teratomu

\author{
Hakan KIRAN, ${ }^{a}$ \\ Sevgi BAKARIŞ, ${ }^{,}$ \\ Gürkan KIRAN, \\ Murat BAKACAK, \\ Deniz ARIKANa
}

Departments of

aGynecology and Obstetrics,

bPathology,

Kahramanmaraş Sütçü İmam University

Faculty of Medicine,

Kahramanmaraş

Geliş Tarihi/Received: 13.05 .2014

Kabul Tarihi/Accepted: 17.09.2014

This study was presented as a poster presentation at $X^{\text {in }}$ Turkish German

Gynecology Congress, 30 April-4 May 2014,

Antalya, Turkey.

Yazışma Adresi/Correspondence:

Murat BAKACAK

Kahramanmaras Sütçü İmam University

Faculty of Medicine,

Department of Gynecology and Obstetrics,

Kahramanmaraş,

TÜRKIYE/TURKEY

muratbakacak46@gmail.com doi: 10.5336/gynobstet.2014-40513

Copyright $(\subset 2015$ by Türkiye Klinikleri

\begin{abstract}
Teratomas are known to be germ cell-derived tumors and occur most commonly in the gonads. Extragonadal occurrence is rarer and reported mainly in the sacrococcigeal area, the mediastinum, retroperitoneal region, the cranial cavity, and the neck region. Teratomas of the fallopian tubes are very rarely encountered in the literature. We describe the occurrence of a mature cystic teratoma of the fallopian tube discovered at laparotomy for an ovarian cystic mass. A salpingectomy was performed with dissection of the pedicle attaching the mass to the fallopian tube and removal of the dermoid cyst. Histopathologic examination showed components from each germ cell layer; therefore, the diagnosis of a mature cystic teratoma of the right fallopian tube was confirmed. Tubal masses should be also considered in the differential diagnosis of all adnexal masses such as mature cystic teratomas of fallopian tubes.
\end{abstract}

Key Words: Fallopian tubes; teratoma

ÖZET Teratomlar germ hücre kaynaklı ve en sık gonadlarda görülen tümörler olarak bilinirler Ekstragonadal görülmeleri nadirdir ve sakrokoksigeal alan, mediasten retroperitoneal alanlarda kranial kavitede ve boyun bölgesinde görülmeleri rapor edilmiştir. Fallop tüplerinin teratomlarına ise literatürde çok daha nadir rastlanmaktadır. Biz kistik ovaryan kitle nedeniyle laparatomi yapıldığı zaman rastlanılan fallop tüpünün matür kistik teratomunu sunuyoruz. Kitlenin fallop tüpüne bağlanan pedikülü diseke edilerek dermoid kist çıkarıldı ve salpenjektomi yapıldı. Histopatolojik inceleme her bir germ hücre tabakası komponentleri görülmüş ve böylece sağ fallopian tüpün matür kistik teratomu tanısı konfirme edilmiştir. Adneksiyal kitlelerin ayırıcı tanısında fallop tüplerinin matür kistik teratomu gibi tubal kitleler de göz önünde bulundurulmalıdır.

Anahtar Kelimeler: Fallop tüpleri; teratom

Turkiye Klinikleri J Gynecol Obst 2015;25(2):134-7

- eratomas are known to be germ cell-derived tumors and occur most commonly in the gonads. Extragonadal occurrence is rarer and reported mainly in the sacrococcigeal area, the mediastinum, the retroperitoneal region, the cranial cavity, and the neck region. Though mature teratomas are the most frequent germ cell tumors of the ovary $(16 \%$ to $20 \%$ of all ovarian neoplasms), the incidence of teratomas of the fallopian tube is extremely low. ${ }^{1}$ None of the reported cases were diagnosed preoperatively. At the present time, only about 60 cases have been reported in the literature. 
The present case confirms that, in examinations prior to surgery, tubal teratomas are usually misdiagnosed because of their protean clinical presentation. We report a mature cystic teratoma arising in the fallopian tube. The mass was noted on magnetic resonance imaging (MRI) prior to surgery for a mature cystic teratoma of the right ovary.

\section{CASE REPORT}

A 43-year-old Turkish woman, G5 P3 A2, was referred to the our hospital, because she was found to have an abdominal mass on ultrasonographic examination. Pelvic examination revealed that the uterus was anteverted, normal in size, mobile and a freely movable and there was a $6 \times 6 \mathrm{~cm}$ cystic and no tender mass in the right adnexal region; the left adnexa were normal. Sonography showed a normal size uterus and a $64 \times 41 \mathrm{~mm}$ mass with an echogenic component $20 \times 25 \mathrm{~cm}$ in size arising from the right adnexa. It was heterogenous in echo texture with few cystic areas. Right ovary could not be seen separately from the mass, left ovary was normal, and there was no free fluid in the pouch of Douglas. MRI revealed a heterogeneous lobulated cystic mass with fat and hemor- rhagic fluid densities $55 \times 45 \times 36-\mathrm{mm}$ in size in the right adnexal region which was suspected of being a mature cystic teratoma of the right ovary (Figure $1)$. Serum concentrations of $\beta$-hCG $(<1 \mathrm{ng} / \mathrm{ml})$, CA19-9 (40.6 U/ml), CA15-3 $(21.5 \mathrm{U} / \mathrm{ml})$ and CA125 $(35.1 \mathrm{U} / \mathrm{ml})$ were within normal limits. Preoperatively, we considered that these findings represented a mature cystic teratoma of the right ovary.

Consequently, she underwent laparotomy. The mass was attached with right ovary, ligamentum latum and uterus. Left tube, both ovaries, and the uterus were normal. Outer surface of the mass was smooth. The right ovary was seen as separately. Right salpingectomy was perfomed for a solid-appearing mass $\sim 4 \times 5 \mathrm{~cm}$ in diameter in the ampullary region arising from the fimbrial end of the right fallopian tube. Grossly, the ampullary portion of right fallopian tube presented a cystic mass of 4,5 $\times 3,5 \times 3 \mathrm{~cm}$ histologically diagnosed as mature cystic teratoma. Histopathologic examination showed components from each germ cell layer; therefore, the diagnosis of a mature cystic teratoma of the right fallopian tube was confirmed (Figure 2).

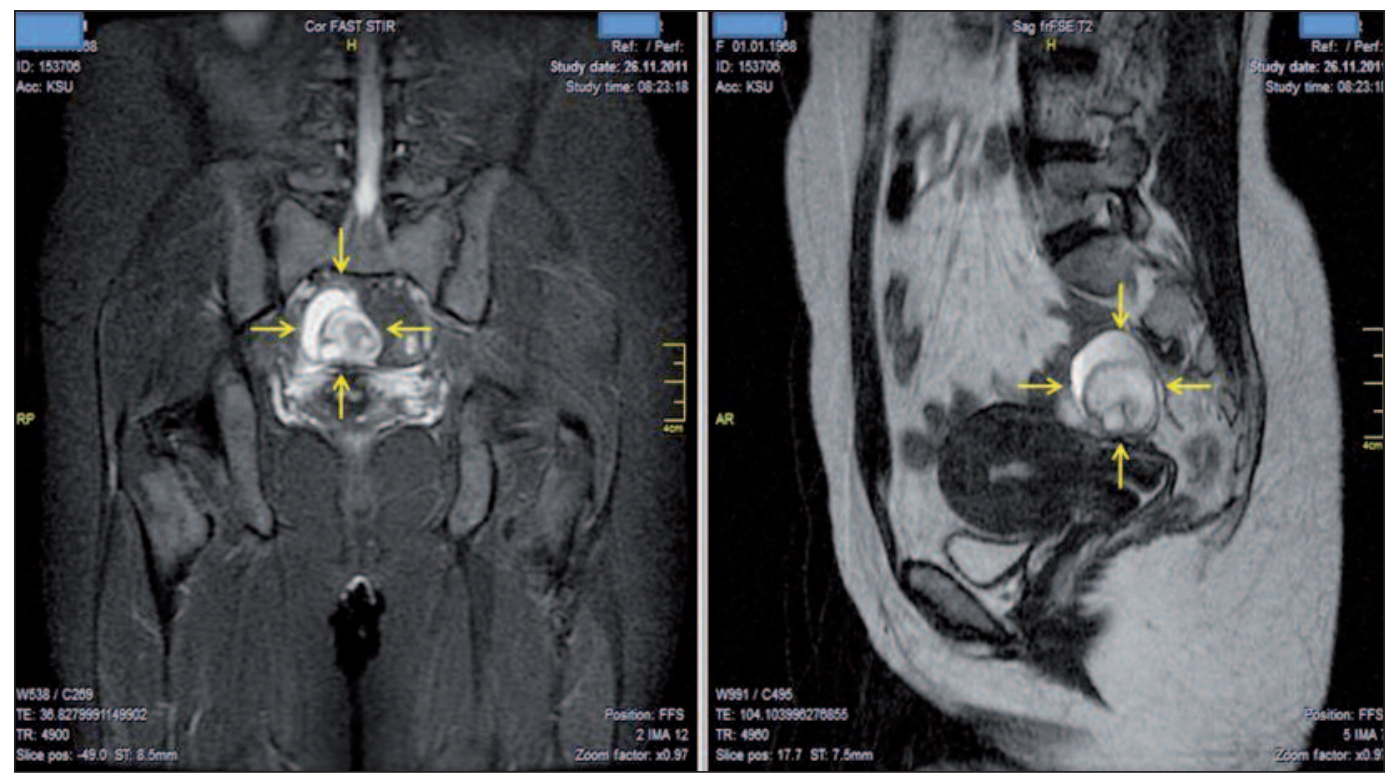

FIGURE 1: Images of pelvic MRI scan. The arrowheads indicate a cystic mass arising within the right ovary; it would be difficult to predict that the mass is a mature cystic teratoma of the fallopian tube from this photograph. 


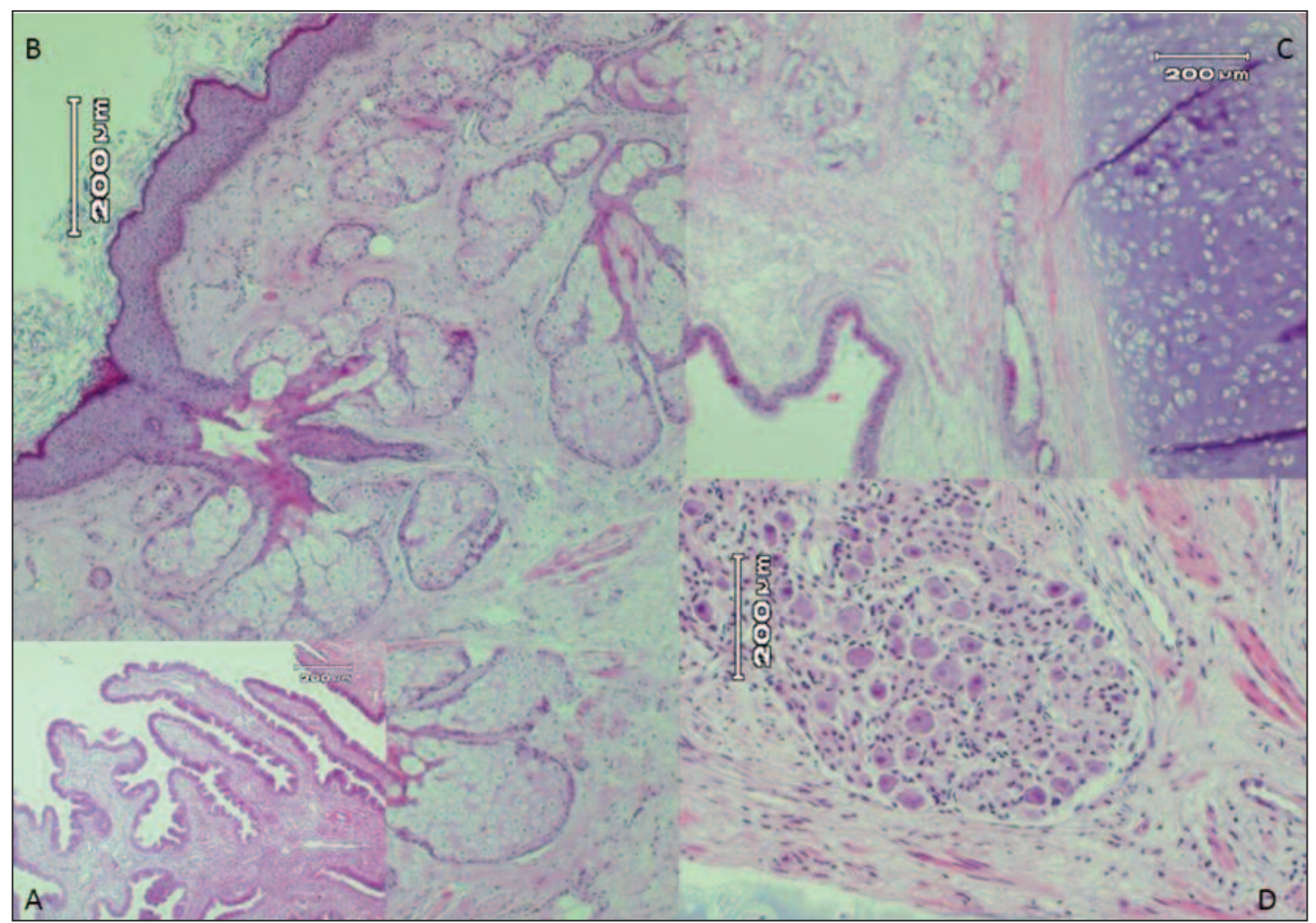

FIGURE 2: Photomicrograph of areas in mature cystic teratoma. A) Fallopian tube (HE, x20). B) The tumor consisted of hair, and sebaceous gland and a cystic space lined by keratinized squamous epithelium (HE, x2-X20). C) Ciliated pseudostratified columnar epithelium lining the cyst wall with mucous gland and mature cartilaginous tissue $(H E, x 20)$. D) Shows ganglion cells in the wall of the cystic lesion.

\section{DISCUSSION}

The pathogenesis of the teratoma is not clearly understood. Teratomas are composed of well-differentiated tissues derived from the three germ-cell layers (ectoderm, mesoderm, and endoderm). In a retrospective study of 80 cases, Dede et al. reported that histopathologic examination reveals one or more of these components in their all cases and also showed a significantly higher rate of histopathologic diagnosis of an ectodermal component in comparison with the patients with unilateral teratoma. ${ }^{[2]}$ The association mature cystic teratoma-ectopic pregnancy is relatively frequent and 6 cases are known to date: 4 in the contralateral tube and 2 in the ipsilateral tube (proximal or distal to the teratoma). ${ }^{3}$ Chao et al. consider the origin to be from germ cells, as teratoma is found most frequently in the gonads and along the known pathway of germ cell migration or from the meiotic germ cells. ${ }^{4}$ The karyotype of all benign teratomas is $46, \mathrm{XX} .{ }^{5}$ About $5-10 \%$ of dermoids (mature teratomas) undergo malignant transformation of any one of the component elements (e.g. adenocarcinoma, choriocarcinoma, thyroid carcinoma, melanoma, but most commonly squamous cell carcinoma) ${ }^{6}$

The anatomical location of the teratoma slightly prevalent in the right tube is usually intraluminal, mainly at isthmic and ampullary level, rarely intramural or subserosal. Most of the tubal teratomas are commonly located in the ampulla or the isthmus. ${ }^{7}$ In our case the teratoma was present at the right ampulla.

Benign teratomas of the ovary are common during the reproductive age. The ages of reported patients ranged from 21 to 60 years and most patients with tubal teratomas were nulliparous. Fallopian tube teratomas have been associated with reduced parity, menstrual irregularity, leukorrhea, postmenopausal bleeding, and abdominal pain. ${ }^{7}$ Our patient was 43 years old and multiparous. 
Such tubal teratomas are usually discovered as an incidental finding on physical and/or radiological examination, or at the time of laparotomy. In examinations prior to surgery, tubal teratomas are often misdiagnosed as ovarian teratomas. In this paper, we describe a mature cystic teratoma of the fallopian tube. This lesion was noted by pelvic MRI prior to laparotomy for a mature cystic teratoma of the right ovary and it was diagnosed at laparotomy. Tubal masses should be considered in the differential diagnosis of all adnexal massess.

\section{REFERENCES}

1. Carinelli SG, Crescini C, Tombesi V, Carinelli I, Bruni M, Senzani F, et al. [Mature teratoma of the ovary. Clinical and anatomo-pathological considerations on 239 cases]. Ann Ostet Ginecol Med Perinat 1982;103(5):343-58.

2. Dede M, Gungor S, Yenen MC, Alanbay I, Duru NK, Haşimi A. CA19-9 may have clinical significance in mature cystic teratomas of the ovary. Int J Gynecol Cancer 2006;16(1):18993.
3. Mekni A, Bouraoui S, Oueslati B, Kchir N, Bellil K, Haouet S, et al. [Mature cystic teratoma of the fallopian tube. A case report]. Tunis Med 2005;83(1):48-50.

4. Chao TJ, Chao J, Kuan LJ, Li YT, Kuo TC, Chang YC, et al. Mature solid teratoma of the fallopian tube associated with uterine leiomyomas. J Chin Med Assoc 2008;71(8): 425-7.

5. Linder D, McCaw BK, Hecht F. Parthenogenic origin of benign ovarian teratomas. $\mathrm{N}$ Engl J Med 1975;292(2):63-6.

6. Doss BJ, Jacques SM, Qureshi F, Chang CH, Christensen CW, Morris RT, et al. Immature teratomas of the genital tract in older women. Gynecol Oncol 1999;73(3):433-8.

7. Mazzarella P, Okagaki T, Richart RM. Teratoma of the uterine tube. A case report and review of the literature. Obstet Gynecol 1972; 39(3):381-8. 